\title{
Accident rate at energy objects in Sakha Republic at low temperatures
}

Dmitry Prokhorov*, and Nikita Pavlov, Larionov Institute of Physical and Technical Problems of the North of Siberian Branch of the Russian Academy of Sciences, Yakutsk, Russia

\begin{abstract}
The work analyzes the effect of low temperatures and other climatic factors on the accident rate and reliability of energy facilities. To represent the causes and analyze the consequences in emergency situations at power plants, descriptions of accidents that occurred in the Sakha Republic were collected and considered. For the analysis, examples are chosen that contain more complete descriptions of the various interrelated causes and consequences of accidents. It was revealed that the greatest number of accidents occurs in the period of low temperatures. High accidents in the summer months are also associated with the climatic features of the republic, mainly with accidents in the power supply system: seasonal melting of permafrost, floods, wildfires and in connection with this drop in power transmission lines, overruns and wire breaks due to storm wind and other.
\end{abstract}

\section{Introduction}

The Sakha Republic is the largest constituent of the Russian Federation and is part of the Far Eastern Federal District. Over $40 \%$ of the territory lies beyond the Arctic Circle and practically the whole territory is in the permafrost zone. Climatic features of the Sakha Republic require increased reliability and efficiency of engineering systems of vital activity of settlements. The duration of the heating season in individual localities reaches 365 days.

Operation of power equipment in difficult climatic conditions leads to accelerated wear and tear and additional costs for repair and restoration, and also dictates increased requirements for the reliability of their operation.In this paper, the influence of the above factors on the current picture of accidents in the Republic's energy facilities is shown.

\section{Accident on power facilities at low temperatures}

For the analysis of emergency situations in the power supply system of the Sakha Republic, accidents data were collected according to the Ministry of Emergencies and energy companies [1-4]. To take into account the change in the ambient temperature of the region, the materials of the Federal State Budget Institution "Yakutsk Administration for Hydrometeorology and Environmental Monitoring" and the Climate Data Archive portal were used $[5,6]$.

\footnotetext{
"Corresponding author: prokhorovdv@gmail.com
} 
According to the analysis of emergency situations it is established that at the energy facilities of the Sakha Republic in the period from 2001 to 2015, there were 784 accidents and accidents happened. In the period from 2011-2013 the additional statistics on the power supply system were taken into account. Some of accidents in the power supply system of the Sakha Republic settlements are shown in the Table 1.

Table 1. Examples of accidents in the power supply system of the Sakha Republic settlements.

\begin{tabular}{|c|c|c|c|c|}
\hline $\begin{array}{l}\text { Date and place } \\
\text { of the accident }\end{array}$ & Material damage & Social damage & Restoration works & $\begin{array}{c}\text { Outside air } \\
\text { temperature on } \\
\text { the day of the } \\
\text { accident, }{ }^{\circ} \mathrm{C}\end{array}$ \\
\hline $\begin{array}{l}\text { 06.12.02, } \\
\text { Lensk, Lensky } \\
\text { ulus }\end{array}$ & $\begin{array}{l}\text { Due to the short circuit } \\
\text { of the power cable } 4 \\
\text { boiler-houses were } \\
\text { stopped in the head } \\
\text { substation of the micro } \\
\text { district "Mukhtui". Boiler } \\
\text { house "Doyarushka" } \\
\text { from 02:30 on February } \\
\text { 10, 2002. The water } \\
\text { supply to the boiler room } \\
\text { is stopped due to the } \\
\text { freezing of the water } \\
\text { channel, water is supplied } \\
\text { from the well in a limited } \\
\text { amount }\end{array}$ & $\begin{array}{l}\text { As a result of the } \\
\text { shutdown of the } \\
\text { boiler houses, } 51 \\
\text { apartments in } 11 \\
\text { residential } \\
\text { buildings were } \\
\text { partially frozen. } \\
\text { Without heat } \\
\text { supply, there are } \\
13 \text { residential } \\
\text { buildings ( } 64 \text { sq.), } \\
\text { Where } 238 \\
\text { residents live, the } \\
\text { sewage system has } \\
\text { been frozen }\end{array}$ & $\begin{array}{l}30 \text { people and } 12 \\
\text { units of equipment } \\
\text { were involved in the } \\
\text { restoration work. } 51 \\
\text { people and } 16 \text { units } \\
\text { of equipment were } \\
\text { involved in the } \\
\text { elimination of the } \\
\text { accident. After } \\
\text { troubleshooting all } \\
\text { boiler houses are } \\
\text { started and put into } \\
\text { operation }\end{array}$ & -48 \\
\hline $\begin{array}{c}26.03 .13 \\
\text { Srednekolymsk, } \\
\text { Srednekolymsky } \\
\text { ulus }\end{array}$ & $\begin{array}{l}\text { There was a fire in the } \\
\text { boiler room number } 3 \\
\text { (oil), together with the } \\
\text { fire department } \\
\text { employees of the branch } \\
\text { of housing and } \\
\text { communal services of } \\
\text { the Sakha Republic, the } \\
\text { outbreak was } \\
\text { extinguished at 19:30. } \\
\text { The cause of the fire is } \\
\text { the explosion of the fuel } \\
\text { hose on the boiler No. } 3 \\
\text { burner }\end{array}$ & & $\begin{array}{l}\text { Electrical equipment } \\
\text { of boilers No. } 3,4 \\
\text { and } 5 \text { is dismantled } \\
\text { and is on drying. } \\
\text { Equipment and } \\
\text { boilers in the boiler } \\
\text { room were not } \\
\text { affected }\end{array}$ & -29 \\
\hline $\begin{array}{c}\text { 14.02.13, } \\
\text { Tiksi, Bulunsky } \\
\text { ulus }\end{array}$ & $\begin{array}{l}\text { The accident first in the } \\
\text { boiler house of the } \\
\text { village, and then on the } \\
\text { main and in-house } \\
\text { heating networks. } \\
\text { Residents were forced to } \\
\text { maintain the temperature } \\
\text { in the homes of electric } \\
\text { heaters. This seriously } \\
\text { increased the load on the } \\
\text { local diesel power plant } \\
\text { and the electric power } \\
\text { grid of Sakhaenergo. Its } \\
\text { maximum rate was } \\
6.2 \mathrm{MW} \text {, with the } \\
\text { planned figure } 4.2 \mathrm{MW} \text {. } \\
\text { Cables began to fail }\end{array}$ & $\begin{array}{l}\text { In connection with } \\
\text { the accident on } \\
\text { February } 14 \text { in the } \\
\text { Bulunsky ulus of } \\
\text { the Sakha } \\
\text { Republic was } \\
\text { introduced a high } \\
\text { alert regime }\end{array}$ & $\begin{array}{l}\text { Special flights on } \\
\text { the route Yakutsk - } \\
\text { Ust-Kuyga-Tiksi } \\
\text { brought emergency } \\
\text { repair teams } \\
\text { consisting of more } \\
\text { than } 50 \text { people and } \\
\text { more than four tons } \\
\text { of goods }\end{array}$ & -48 \\
\hline
\end{tabular}


From the analysis of accidents it was revealed that the most frequent failures in the power supply system, the least frequent failure occurs in the fuel supply system (Fig. 1). Extensive power lines on the territory of the republic, in particular in the Arctic zone, determine the high probability of accidents in severe climatic conditions. The peculiarity of the electric grid economy of the Sakha Republic is the transmission of electricity over significant distances and the operation of electric grids in conditions of sharply continental climate and permafrost. In total, more than 27 thousand $\mathrm{km}$ of power transmission lines of all voltage levels are in operation in the republic, including more than 1,800 km of 10-6-0.4 $\mathrm{kV}$ overhead lines in the Arctic zone.

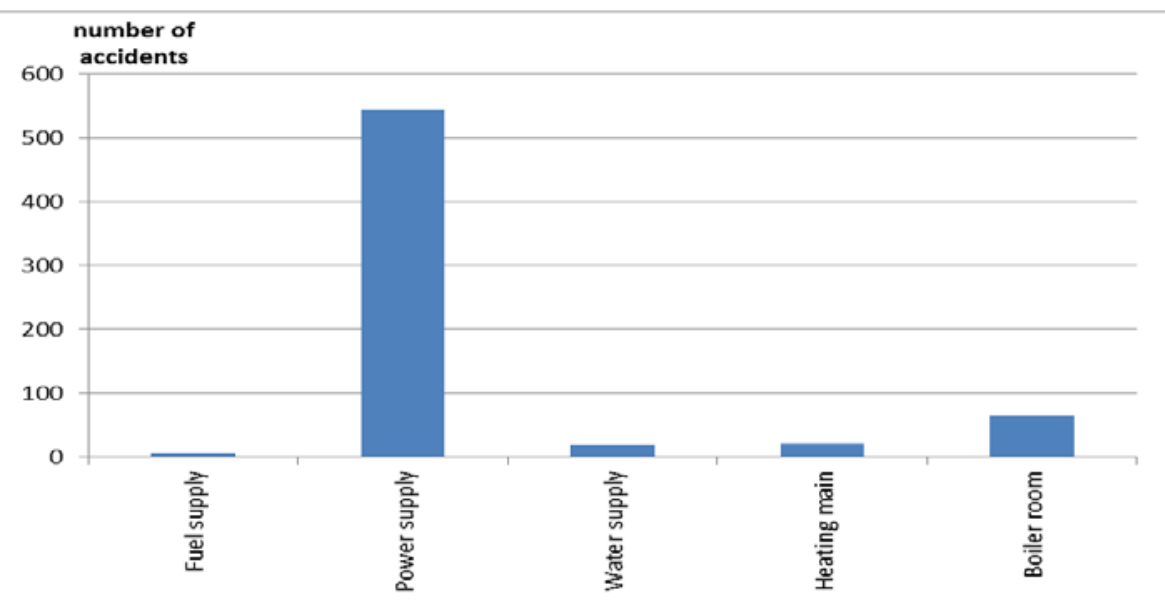

Fig. 1. Distribution of accidents by system elements.

The data on the distribution of the number of accidents during the year to months are shown in Fig. 2. In the Sakha Republic about thirty accidents and emergencies occur at life support facilities and energy systems. About $50 \%$ of all accidents and emergencies occur in Yakutsk, Mirninsky, Lensky and Aldan districts, as the most populated and, accordingly, have developed infrastructure. As can be seen from the figure, the intensity of accidents increases at low temperatures, i.e. in the coldest months of the winter heating period. High accident rate in the summer months is also associated with the climatic features of the republic, mainly with accidents in the power supply system: seasonal melting of permafrost, floods, forest fires and in connection with this drop in power transmission lines, overruns and wire breaks due to storm wind and other.

A significant share of accidents and equipment failures is directly or indirectly related to errors of designers, equipment manufacturers, personnel of operating and contracting organizations, etc. (related to the "human factor") [7, 8]. Based on the results of the accident investigations, it was found that in 122 accidents and emergencies, the "human factor" in various forms was the decisive factor (cause). The frequency of their distribution in the regions of the Sakha Republic is reflected in Fig. 3a. Fig. 3b shows a map reflecting the impact of this factor on the occurrence of accidents on the map of the Sakha Republic. Fig. 3c shows a map of distribution of accidents at the facilities of the Sakha Republic energy systems without taking into account the "human factor". 


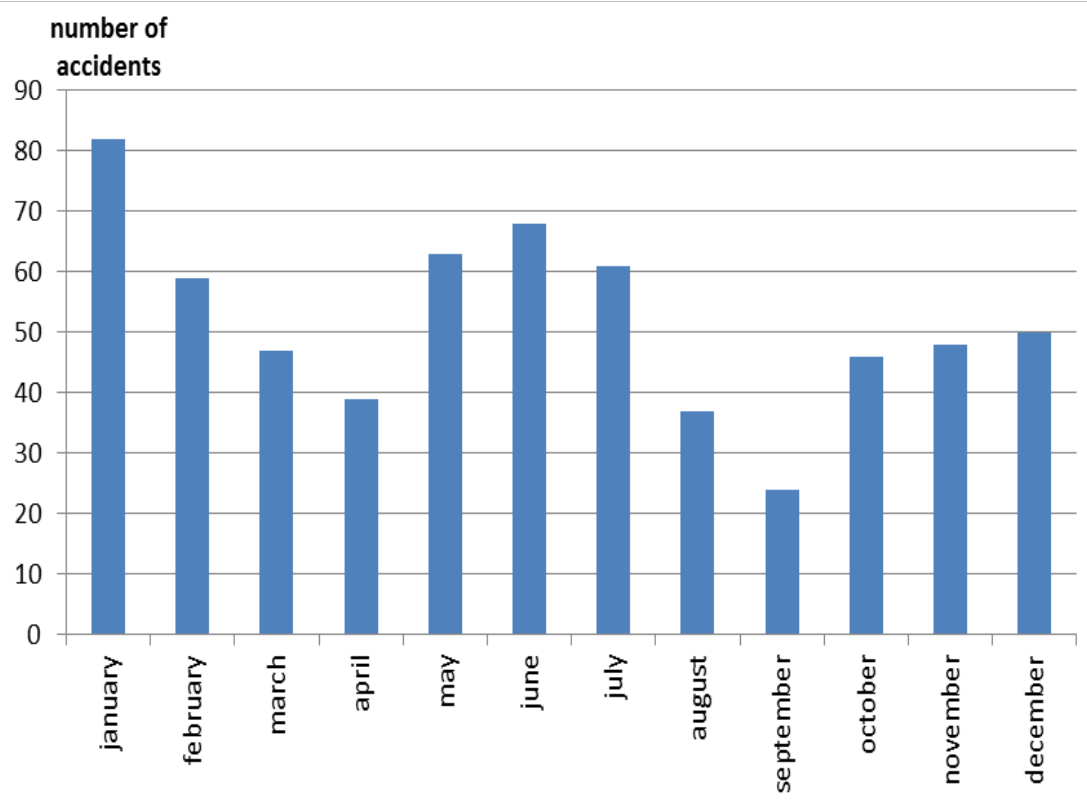

Fig. 2. Distribution of accidents by month.

The heat supply system of the Sakha Republic is characterized by a high degree of wear and tear on the equipment of thermal energy sources and heat networks, low efficiency and reliability, poor level of comfort in buildings, high heat losses, difficulty in delivering fuel, abnormal fuel losses during transportation, low reliability of heat supply, use of installed capacity, which shows, on the one hand, a high degree of redundancy of heat supply sources, and with others inefficiency of equipment use.

Comparison of the climatic characteristics that determine the estimated hourly and annual heat costs for heating in different regions of Russia and the Far East shows that even Yakutsk, which is not the city with the lowest temperatures in the republic, belongs to the coldest cities of the Far East.

The length of heat networks in the Republic in 2015 was 3.91 thousand $\mathrm{km}$, with $82 \%$ of them distribution networks with a diameter of up to $200 \mathrm{~mm}$. According to statistics, wear of heat networks in 2015 did not exceed $24.9 \%$, in fact the actual level of wear is much higher. According to the State Unitary Enterprise Housing and Communal Service of the Sakha Republic, which is responsible for more than a third of the thermal networks of the Sakha Republic, their depreciation amounts to $57 \%$.

As noted in the Investment Program of the State Unitary Enterprise Housing and Communal Service of the Sakha Republic for 2012-2017 and the main directions of the development of the enterprise until 2025 "the laying of heat traces in many areas of the Republic above ground, the thermal insulation of pipelines is made with mineral wool, heat-insulating PVC sheets. Isolation in some areas is in an unsatisfactory state, which leads to additional thermal losses in the networks. The number of sections of heat traces that are not adequately insulated is, according to various estimates, 40 to $60 \%$. Wooden boxes, in which some pipes with insulation from wood chips are laid, are exposed to atmospheric precipitation, which is a negative factor" [9]. 


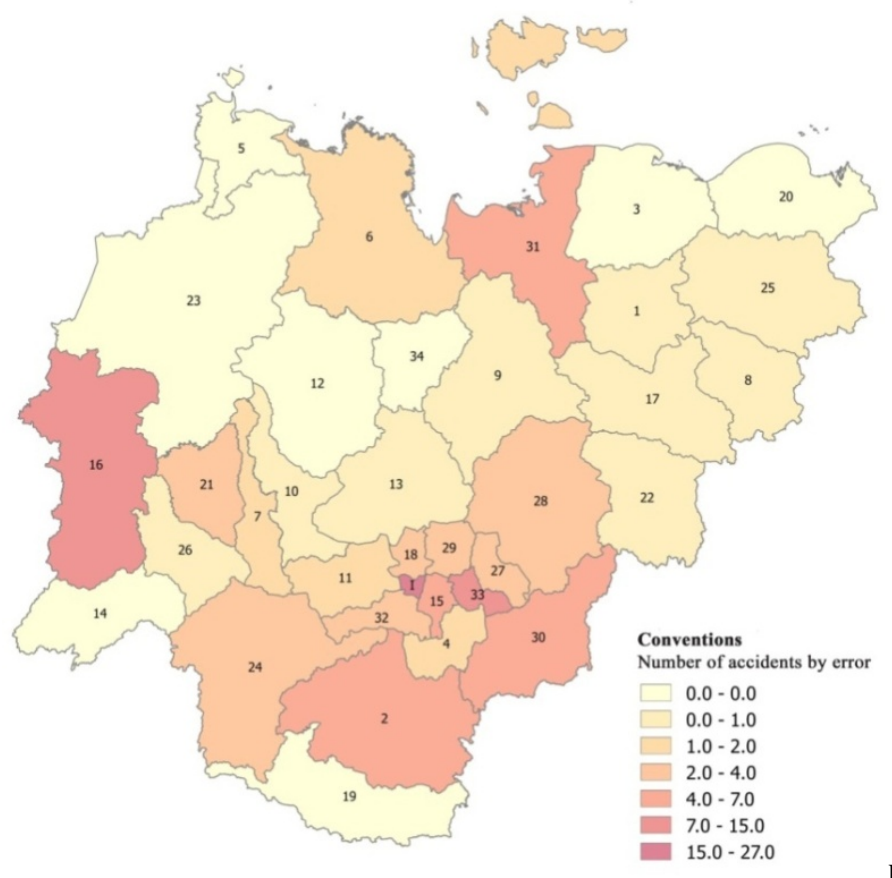

b) 


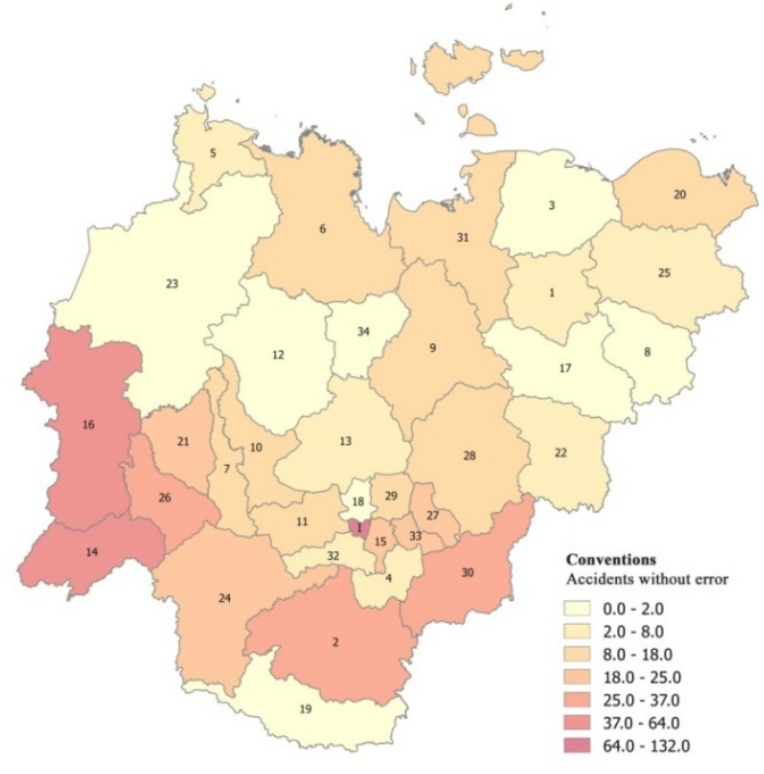

c)

1 - Abyisk ulus, 2 - Aldan ulus, 3 - Allaikhovsky ulus, 4 - Amginskiy ulus, 5 - Anabar national ulus, 6 - Bulunsky ulus, 7 - Verkhnevilyuisky ulus, 8 - Verkhnekolymsky, 9 - Verkhoyansk ulus,

10 - Viluisky ulus, 11 - Mountain Ulus, 12 - Zhigansky ulus, 13 - Kobyaysky ulus, 14 - Lensky ulus, 15 - Megino-Kangalas ulus, 16 - Myrninsky district, 17 - Momsky ulus, 18 - Namsky ulus,

19 - Neryungri district, 20 - Nizhnekolymsky ulus, 21 - Nyurbinsky ulus, 22 - Oymyakonsky ulus,

23 - Oleneksky ulus, 24 - Olekminsky ulus, 25 - Srednekolymsky ulus, 26 - Sun , 27 - Tattinsky ulus, 28 - Tomponsky ulus, 29 - Ust-Aldansky ulus, 30 - Ust-Maysky ulus, 31 - Ust-Yansky ulus, 32 - Khangalassky ulus, 33 - Churapchinsky ulus, 34 - Eveno-Bytantai ulus , I -Yakutsk

Fig.3. a) -Accidents at the facilities of the Sakha Republic energy systems; b) - Accidents at the facilities of the Sakha Republic energy systems taking into account the "human factor"; c) - Accidents at the facilities of the Sakha Republic energy systems without taking into account the "human factor".

The main specific features in the heat supply of the Sakha Republic:

1. Unsatisfactory technical level, due to insufficient equipment of automation, accounting and control systems. Obsolete technical solutions do not allow efficient transportation and use of thermal energy, which results in: huge over-expenditure of fuel and energy; frequent accidents; excessively high costs in heat supply systems.

2. Low level of equipping with centralized heat supply. In most areas, there is no possibility to provide district heating, water supply and sanitation services, which negatively affects the quality of life of the population [10].

3. High degree of housing stock depreciation. Specific consumption of heat energy for heating residential buildings is characterized by a wide range of variation in the values of the indicator. A high level of heat consumption is associated with a significant deterioration of the housing stock. The republic is among the regions of the Russian Federation with the largest share of dilapidated and emergency housing $-16.6 \%$. One of the reason for this is that almost two-thirds of the republic's housing stock consists of wooden houses (about $60 \%$ of the total area) [11].

4. Significant deterioration of equipment and heating networks due to untimely repair and replacement. Losses in heat networks continue to increase, on average in the Sakha Republic in 2015 they amounted to $24.9 \%$, in some parts of the republic the level of losses reaches about $40 \%$ (Aldansky, Ust-Yansky, etc.) [12]. All this testifies that the heat supply network of the republic requires special attention and significant investments in the 
modernization of existing heating networks and in the construction of new heating mains from new sources of heat supply.

To estimate the frequency of accidents occurrence at power facilities that occurred at negative and positive temperatures, data were selected without taking into account the "human factor" (Table 2).

Table 2. Temperature on the day of the accident.

\begin{tabular}{|c|c|c|}
\hline & Number of accidents & Share, $\%$ \\
\hline below $0{ }^{\circ} \mathrm{C}$ & 317 & 47,9 \\
\hline above $0{ }^{\circ} \mathrm{C}$ & 335 & 50,6 \\
\hline Total & 652 & 98,5 \\
\hline Temperature unknown & 10 & 1,5 \\
\hline Total & 662 & 100,0 \\
\hline
\end{tabular}

As can be seen from Table 3, the highest frequency of accidents occurs in the range of temperature fluctuations per day from 0 to $9.9^{\circ} \mathrm{C}$. Of all 652 accidents, the maximum is reached with a temperature change from 5 to $9.9^{\circ} \mathrm{C}$ and the share is $25.8 \%$. With a further increase in temperature fluctuations, the frequency of accidents is slightly reduced and reaches $19.8 \%$ in the range from 10 to $14.9^{\circ} \mathrm{C}$ and $18.6 \%$ from 15 to $19.9^{\circ} \mathrm{C}$. The highest temperature fluctuations per day occur less frequently, therefore, accidents are also less. So, starting from $20^{\circ} \mathrm{C}$, the number of accidents were 53 , from $25^{\circ} \mathrm{C}$ were 9 , and above $30^{\circ} \mathrm{C}$ temperature fluctuations, which happens extremely rarely, there were only 3 accidents.

Table 3. Temperature difference in ranges.

\begin{tabular}{|c|c|c|}
\hline Temperature & Number of accidents & Share, $\%$ \\
\hline from 0 to $4,9^{\circ} \mathrm{C}$ & 162 & 24,5 \\
\hline from 5 to $9,9^{\circ} \mathrm{C}$ & 171 & 25,8 \\
\hline from 10 to $14,9^{\circ} \mathrm{C}$ & 131 & 19,8 \\
\hline from 15 to $19,9^{\circ} \mathrm{C}$ & 123 & 18,6 \\
\hline from 20 to $24,9^{\circ} \mathrm{C}$ & 53 & 8,0 \\
\hline from 25 to $29,9^{\circ} \mathrm{C}$ & 9 & 1,4 \\
\hline from 30 to $34,9^{\circ} \mathrm{C}$ & 3 & 0,5 \\
\hline Total & 652 & 98,5 \\
\hline Temperature unknown & 10 & 1,5 \\
\hline Total & 662 & 100,0 \\
\hline
\end{tabular}

\section{Conclusion}

The analysis of accidents shows that the tendency to increase the risk of accidents in power supply systems is mainly caused by the following reasons:

1. Influence of climatic conditions on the peculiarity of operation of engineering systems (low temperature, gusts of wind, flood, defrost of frozen grounds of energy facilities);

2. High wear of engineering systems and equipment; 
3. Insufficient level of development of the safety management system in the operation of electrical, water and heat networks;

4. Low qualification of maintenance personnel or the so-called "human factor".

Elements of the power supply system for consumers in the North in terms of danger are located in the following order: boiler room, heating networks, power supply, water supply and fuel supply. The most dependent and vulnerable element, depending on the reliability of the subsystems above the functional scheme of power supply, are heat networks.

\section{References}

1. Materials of PJSC "Yakutskenergo" 2001-2015 (in Russian)

2. Materials of JSC "Sakhaenergo" 2001-2015 (in Russian)

3. Materials of the State Unitary Enterprise of Housing and Communal Service of the Sakha Republic (in Russian)

4. Materials of the EMERCOM of Russia (in Russian)

5. http://www.rp5.ru

6. Materials of Federal State Budget Institution "Yakutian Department of Hydrometeorology and Environmental Monitoring" (in Russian)

7. A. Lieberman. Technogenic safety: the human factor. Saint Petersburg, 101 p. (2006) (in Russian)

8. A. Zubareva, I. Gaydey. Risks of the human factor in the development of emergency situation. Problems of Economics and Oil and Gas Complex Management, vol. 12, pp. 35-38, (2015) (in Russian)

9. Decree of the Government of the Sakha Republic on October 22, 2012 N 1147-r On approval of the Investment Program of the State Unitary Enterprise Housing and Communal Service of the Sakha Republic for 2012-2017 and the main directions of the enterprise development until 2025 (in Russian)

10. A. Starostina, N. Pavlov. Current state and main problems of heat power industry of the Sakha Republic. Proceedings of the XVII All-Russian scientific and practical conference of young scientists, graduate students and students, with international participation in Neryungri, dedicated to the 60th anniversary of the formation of the Yakutsk State University, Sections 1-3, pp. 156-159 (2016) (in Russian)

11. The State Program of the Sakha Republic "Provision of high-quality housing and communal services and development of the electric power industry for 2012-2017" (in Russian)

12. Housing and communal services of the Sakha Republic. Statistical compilation. Federal State Statistics Service. Yakutsk, 87 p. (2016) (in Russian) 